\title{
PENERAPAN LESSON STUDY MELALUI METODE PROJECT BASED LEARNING UNTUK MENINGKATKAN KEAKTIFAN MAHASISWA DALAM PROSES PEMBELAJARAN DI FKIP UNPAS
}

\author{
${ }^{1}$ Saiful Almujab ${ }^{\bowtie},{ }^{2} S$ Marten Yogaswara, ${ }^{3}$ Afief Maula Novendra, dan ${ }^{4}$ Leni Maryani \\ UNIVERSITAS PASUNDAN BANDUNG
}

Info Artikel

Sejarah Artikel:

Diterima 8 Mar 2018

Direvisi 13 Mar 2018

Dipublikasikan Jun 2018

\section{Keywords:}

Lesson study, $P B L$,

Student activities

\begin{abstract}
This article describes more comprehensive ways to apply lesson study to learning, to maintain its continuity so as to improve the effectiveness of learning in FKIP Universitas Pasundan Bandung. To see the increased effectiveness of learning in learners, this study uses action research. In practice, this research uses two research cycles. Each cycle of Lesson Study has four stages: preparing, performing, reflecting (checking or seeing) and follow up (act). The subjects of the study are 3rd graders, Economic Education Study Program, Faculty of Teacher Training and Education, Universitas Pasundan Bandung . Based on the observation result in this cycle, in general the implementation of the action has not achieved satisfactory results. While based on the results of questionnaires about the implementation of learning obtained information that most learners feel happy with economic learning by using learning methods PBL. This is because learning by using PBL is able to generate student learning activities in learning
\end{abstract}

\begin{abstract}
Abstrak
Artikel ini menguraikan cara-cara yang lebih komprehensif bagaimana mengaplikasikan lesson study pada pembelajaran, menjaga keberlangsungannya hingga dapat meningkatkan efektifitas pembelajaran di FKIP Universitas Pasundan Bandung. Untuk melihat peningkatan efektifitas pembelajaran pada peserta didik, penelitian ini menggunakan penelitian tindakan. Dalam pelaksanaannya, penelitian ini menggunakan dua siklus penelitian. Pada setiap siklus pelaksanaan lesson study memiliki empat tahapan yaitu melakukan persiapan (plan), pelaksanaan (do), refleksi (check atau see) dan tindak lanjut (act). Subjek penelitian adalah mahasiswa tingkat 3 (tiga), Program Studi Pendidikan Ekonomi, Fakultas Keguruan dan Ilmu Pendidikan, Universitas Pasundan Bandung. Berdasarkan hasil observasi pada siklus ini, secara umum pelaksanaan tindakan belum mencapai hasil yang memuaskan. Sementara berdasarkan hasil kuisioner tentang pelaksanaan pembelajaran diperoleh informasi bahwa sebagaian besar peserta didik merasa senang dengan pembelajaran ekonomi dengan menggunakan metode belajar PBL. Hal ini disebabkan karena pembelajaran dengan menggunakan PBL mampu membangkitkan aktifitas belajar mahasiswa dalam pembelajaran.
\end{abstract}

(C) 2018 Universitas Muria Kudus
p-ISSN 2087-9385 e-ISSN 2528-696X

\footnotetext{
Program Studi Pendidikan Guru Sekolah Dasar

Fakultas Keguruan dan Ilmu Pendidikan Universitas Muria Kudus

Kampus UMK Gondangmanis, Bae Kudus Gd. L. 1t I PO. BOX 53

Kudus

Tlp (0291) 438229 ex.147 Fax. (0291) 437198

E-mail: saifulalmujab@unpas.ac.id
}

Alamat korespondensi: 


\section{PENDAHULUAN}

Kualitas pendidikan menentukan seberapa banyak dan seberapa baik anak belajar dan sejauh mana dapat diterjemahkan ke dalam berbagai manfaat pribadi, sosial. Pembelajaran sebagai bagian dalam pendidikan merupakan ujung tombak penentu tercapai tidaknya tujuan pendidikan, sehingga mutu pembelajaran berkaitan erat dengan mutu pendidikan (Nursafitri 2015). Untuk mencapai pelaksanaan pendidikan tersebut, perlu inisiatif untuk terus melakukan peningkatan kualitas pendidikan. Inisiatif tersebut perlu dipusatkan pada peningkatan pengajaran dan belajar sekaligus dengan memperhatikan semua faktor, seperti materi masukan, kompetensi guru, manajemen pendidikan yang memungkinkan dan mendukung perubahan pada pengajaran dan pembelajaran (Barrett, Tikly, Guoxing, \& Sajid 2007). Untuk itu, peningkatkan kualitas pendidikan yang mengarah pada peningkatan mutu pembelajaran menjadi fokus pemerintah Indonesia dari waktu ke waktu. Banyak proyek yang berhubungan dengan pendidikan dan pengembangan pendidikan telah dilakukan baik oleh lembaga pemerintah atau dengan cara program kerja sama yang melibatkan lembaga asing.

Pembelajaran yang berkualitas tinggi adalah kunci untuk perbaikan pendidikan dalam mewujudkan fitur penting dari pembelajaran profesional yang kuat (Suratno 2012). Sampai saat ini banyak yang berpendapat bahwa kualitas pendidikan berpusat pada input sistem, seperti infrastruktur dan rasio murid-guru, dan konten kurikuler. Namun dalam beberapa tahun terakhir, perhatian lebih difokuskan pada proses pendidikan yaitu bagaimana pengajar menggunakan input untuk membingkai pengalaman belajar yang bermakna bagi speserta didik. Mereka merupakan faktor kunci dalam memastikan proses pembelajaran yang berkualitas (UNICEF 2000).

Pengajar yang berkualitas adalah mereka yang paling mampu membantu peserta didik mereka belajar, memiliki penguasaan mendalam terhadap materi pelajaran dan pedagogi (Darling-Hammond 1997). Untuk mencapai hal ini, tidak cukup mengukur apa yang dipelajari peserta didik: penting untuk menargetkan pengalaman kelas yang secara mendasar membentuk pembelajaran peserta didik, dan menekankan berbagai keterampilan yang dibutuhkan untuk kesejahteraan seumur hidup dan kohesi masyarakat.

Salah satu peningkatan kualitas pendidikan di Indonesia yang mengarah pada peningkatan kualitas pembelajaran adalah kerjasama teknis antara Badan Kerjasama Internasional Jepang (Japan International Cooperation Agency) dan lembaga pendidikan guru di Indonesia. Mereka memperkenalkan "lesson study", suatu bentuk pengembangan profesional secara luas dipraktekkan di Jepang yang telah dikembangkan sebagai pendekatan untuk meningkatkan kompetensi dan profesionalisme guru. Tujuannya adalah untuk mengetahui tentang pengajaran melalui pemantauan pembelajaran murid dalam menanggapi metode pengajaran yang berbeda.

Lesson study (atau jugyō kenkyū) adalah proses peningkatan pengajaran yang berasal dari pendidikan dasar Jepang dan menerapakan praktik pengembangan profesional yang meluas. Bekerja dalam kelompok kecil, para guru berkolaborasi satu sama lain, bertemu untuk mendiskusikan tujuan pembelajaran, merencanakan pelajaran kelas aktual atau disebut "research lesson", mengamati bagaimana gagasan mereka bekerja dalam pelajaran langsung dengan peserta didik, dan kemudian melaporkan hasilnya sehingga guru lain bisa memanfaatkannya (Takahashi \& Thomas, 2014).

Lesson study bukan metode pembelajaran atau strategi pembelajaran, tetapi dalam lesson study dapat dipilih dan diterapkan berbagai metode atau strategi pembelajaran yang sesuai dengan situasi, kondisi, atau masalah pembelajaran yang dihadapi dosen dan mahasiswa. Dalam lesson study, dosen harus mengubah proses pembelajaran klasikal yang berorientasi kepada pengajar (Teacher Center Learning) menjadi pembelajaran yang berpusat pada mahasiswa (Student Center Learning) (Wiharto, 2017).

Awalnya lesson study dikembangkan sebagai praktik pendidikan di periode Meiji di Jepang, lesson study berfungsi sebagai sarana untuk memungkinkan guru berkembang dan mempelajari praktik pengajaran mereka sendiri (Baba 2007). Sehingga lesson study bukan metoda atau strategi pembelajaran tetapi kegiatan lesson study dapat menerapkan berbagai metode/strategi pembelajaran yang sesuai dengan situasi, kondisi, dan permasalahan yang dihadapi guru (Dinus 2016). Melalui beberapa pelajaran penelitian di tingkat kelas yang berbeda, sekolah bekerja menuju visi bersama tentang bagaimana mencapai tujuan mereka. Tujuan umum lain dari pelajaran pelajaran berbasis sekolah adalah untuk mengatasi perubahan dalam Kursus Studi 
Nasional, yang direvisi setiap 9 tahun sekali (Takahashi \& Thomas 2014).

Keberhasilan Jepang dalam mengembangkan lesson study mulai diikuti negara lain (Putri, Atmazaki, \& Syahrul 2013). Di Asia LS (lesson study) sekarang digunakan di luar Jepang seperti di Singapura, Hong Kong,
Indonesia, dan Cina. Di Barat LS (lesson study) digunakan di negara-negara termasuk Amerika Serikat, Inggris, Swedia dan Kanada (Lewis, 2002). Penggunaan lesson study secara masive disebabkan karena lesson study diyakini membantu guru berpengalaman untuk mengajar (Dudley 2014).

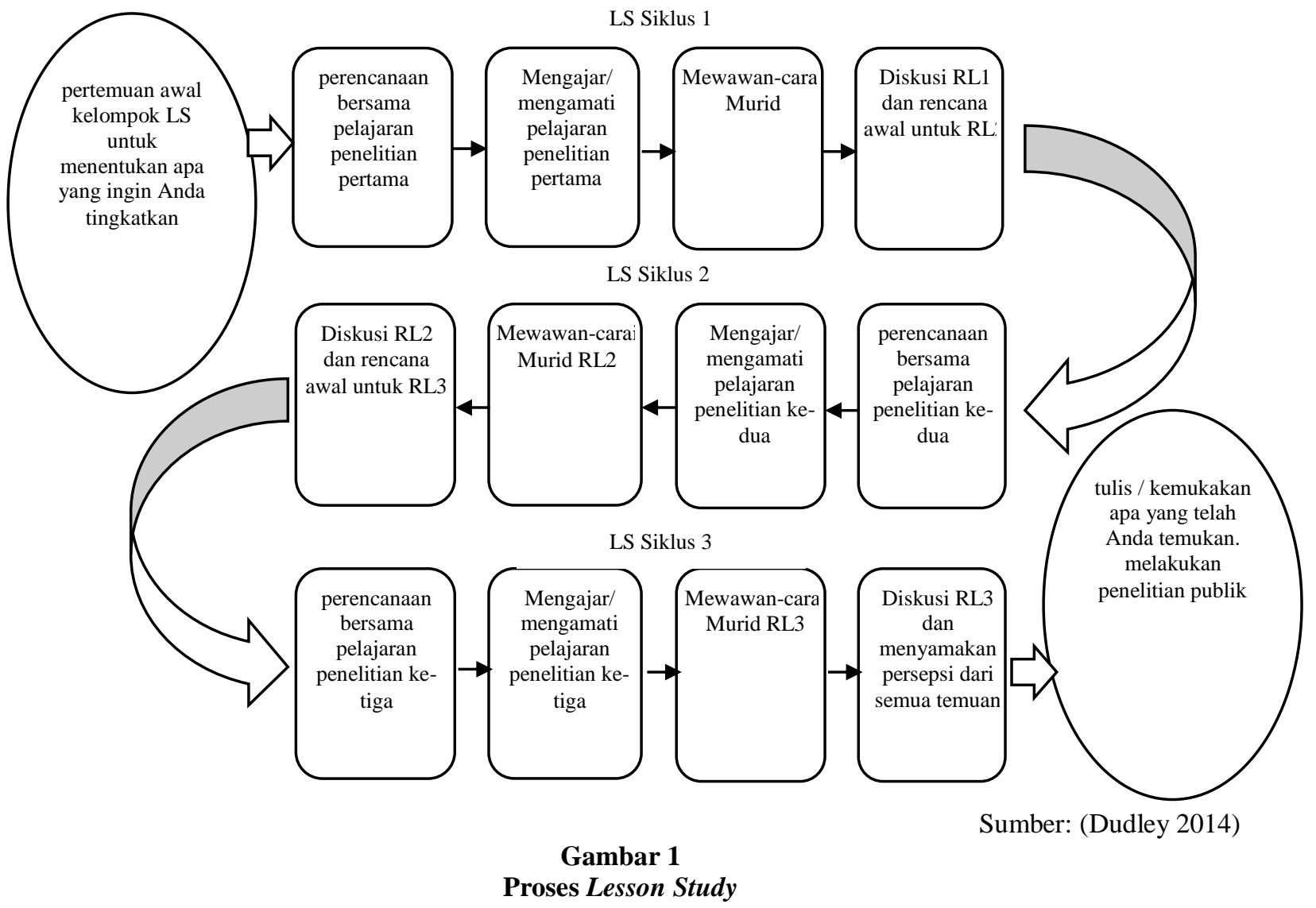

Karakteristik unik dari lesson study adalah bahwa prilaku peserta didik merespon penggunaan metode pembelajaran guru menjadi objek yang diobservasi, bukan tentang bagaimana guru mengajar, apa yang salah dan apa yang benar. 


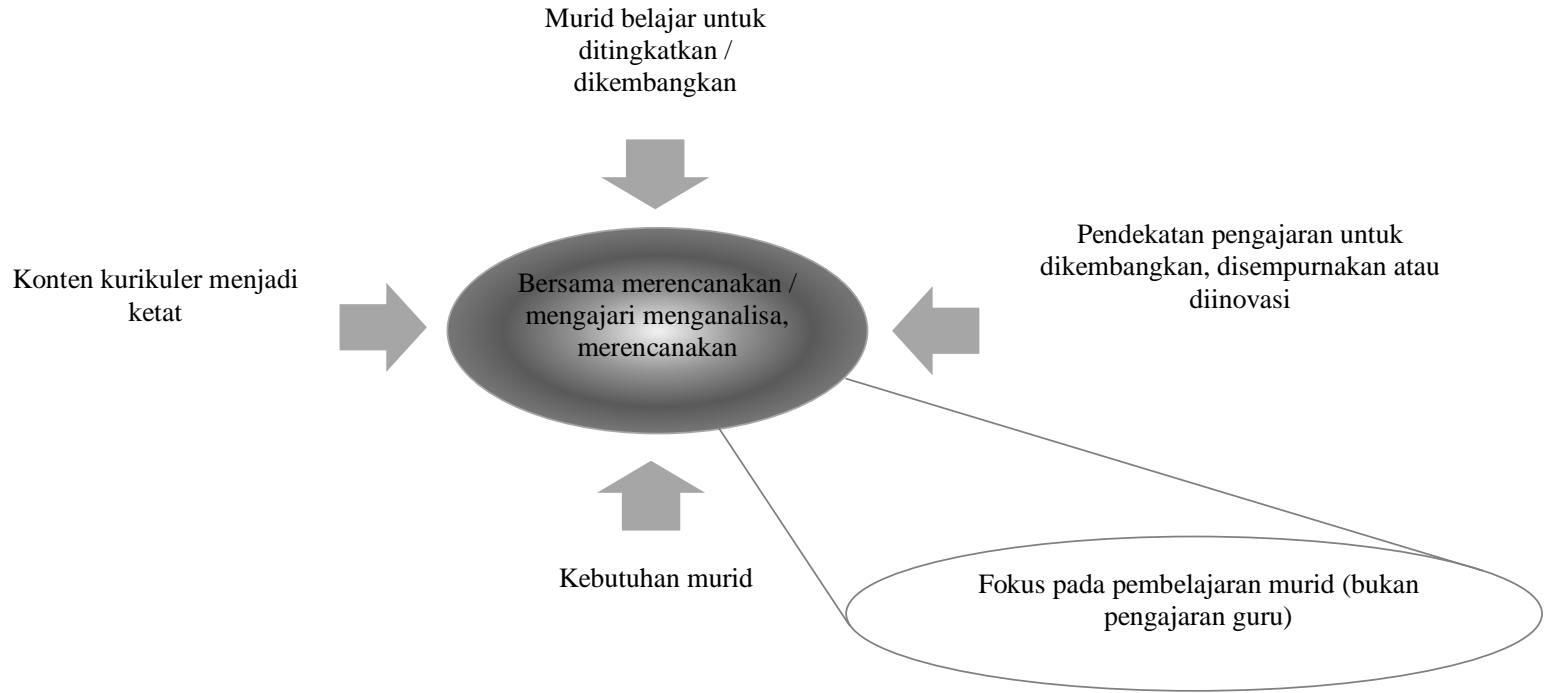

Gambar 2

Sumber: (Dudley 2014)

\section{Pembelajaran dalam Lesson Study}

Perencanaan pengamatan pembelajaran disusun bersama untuk menangani masalah pembelajaran, daripada berfokus pada kinerja guru secara individual (Cajkler, Wood, Norton, Pedder, \& Xu 2015). Sehingga menjaga agar peserta didik selalu menjadi detak jantung kegiatan pengembangan profesi guru (Krisnawan 2010).

Fakultas Keguruan dan Ilmu Pendidikan (FKIP) Universitas Pasundan Bandung sebagai Lembaga Pendidik dan Tenaga Kependidikan (LPTK) yang terus berupaya meningkatan kualitas pembelajaran menilai bahwa lesson study dapat dijadian jalan untuk mencapai pembelajaran yang berkualitas. Mengingat bahwa Penggunaan Lesson Study yang dilakukan ratusan guru di AS sebagai pendekatan pembinaan untuk meningkatkan kemajuan peserta didik menunjukkan dampak yang cukup besar dari tahun ke tahun (Dudley 2014). Oleh karena itu, artikel ini menguraikan cara-cara yang lebih komprehensif bagaimana mengaplikasikan lesson study pada pembelajaran, menjaga keberlangsungan hingga dapat meningkatkan pembelajaran berkualitas di FKIP Universitas Pasundan Bandung.

\section{METODE PENELITIAN}

Lesson Study merupakan kegiatan pendampingan dan pembinaan terhadap pengajar mulai dari melakukan persiapan (plan), pelaksanaan (do), refleksi (check atau see) dan tindak lanjut (act) (Wiharto 2017). Kegiatan ini bukan sebuah kegiatan sesaat tetapi kegiatan yang terus menerus, berkesinambungan dan sebuah upaya untuk mengaplikasikan prinsip-prinsip dalam Total Quality Management (Wiharto 2017).

Terdapat tiga jenis penelitian untuk mempertahankan praktik lesson study:

1. Perluasan basis pengetahuan yang bersifat deskriptif;

2. Penjelasan mengenai mekanisme inovasi yang diterapkan pada LS; dan

3. Penelitian Siklus berulang untuk melakukan perbaikan (Suratno 2012)

Penelitian ini menggunakan penelitian tindakan. Penelitian tindakan dapat didefinisikan sebagai "pendekatan di mana peneliti tindakan dan klien berkolaborasi dalam diagnosis masalah dan dalam pengembangan solusi berdasarkan diagnosis" (Bryman \& Bell 2011). Penelitian tindakan merupakan cara untuk memperbaiki masalah pemecahan masalah.

Ada dua jenis penelitian tindakan: partisipatif dan praktis (Stringer 2014). Strategi penelitian tindakan adalah menghasilkan panduan untuk praktik terbaik (Denscombe 2017). Kemmis \& McTaggart (2007) menyatakan penelitian tindakan adalah studi partisipatif spiral yang terdiri dari: 


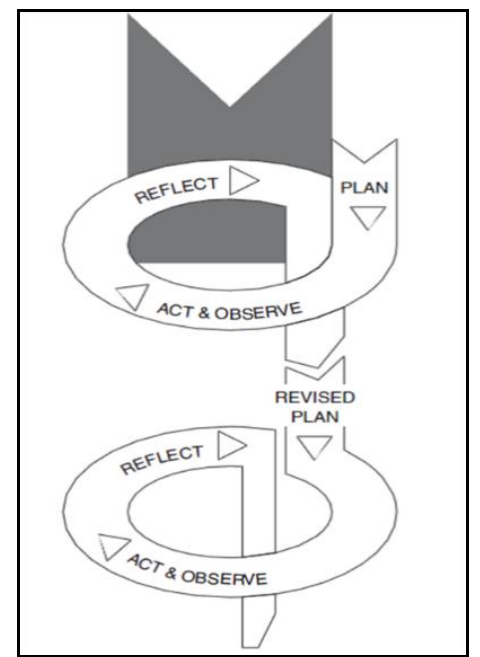

Sumber: (Kemmis \& McTaggart 2007)

Gambar 3

Penelitian Tindakan Spiral

1) Merencanakan untuk memulai perubahan

2) Melaksanakan perubahan (acting) dan mengamati proses implementasi dan konsekuensinya

3) Merefleksikan proses perubahan dan perencanaan ulang

4) Bertindak dan mengamati

5) Merefleksikan lagi, dan seterusnya...

Dalam pelaksanaannya penelitian ini menggunakan dua siklus penelitian. Pada setiap siklus pelaksanaan lesson study memiliki empat tahapan yaitu melakukan persiapan (plan), pelaksanaan (do), refleksi (check atau see) dan tindak lanjut $(a c t)$.

Subjek penelitian adalah mahasiswa tingkat 3 (tiga) Program Studi Pendidikan Ekonomi Fakultas Keguruan Dan Ilmu Pendidikan Universitas Pasundan Bandung yang berjumlah 36 mahasiswa. Untuk mendapatkan data yang valid mengenai apakah proses pembelajaran yang dilakukan menuju ke arah yang lebih baik, maka peneliti menggunaka dua instrumen yaitu hasil belajar peserta didik dan hasil pengamatan observer. Prosedur pengumpulan data dalam penelitian ini menggunakan teknik observasi, wawancara, dan tes tertulis.

\section{HASIL DAN PEMBAHASAN}

\section{Mengaplikasikan Lesson Study pada Pembelajaran}

Lesson study merupakan kegiatan pendampingan dan pembinaan terhadap pengajar mulai dari melakukan persiapan (plan), pelaksanaan (do), refleksi (check or see) dan tindak lanjut (act) (Wiharto 2017).

\section{a) Tahapan Perencanaan (Plan)}

Sebelum melakukan perencanaan, terlebih dahulu telah ditentukan pengajar yang akan melakukan open lesson. Kegiatan open lesson adalah proses pembelajaran yang akan diamati dan diobservasi pada kegiatan lesson study. Pengajar yang akan melakukan open lesson atau disebut juga dosen model secara bersama-sama dengan pengajar lain yang terlibat dalam kegiatan lesson study menyusun lesson desain.

Lesson design merupakan rencana kegiatan yang akan dilakukan pada saat pembelajaran berlangsung. Lesson design yang disusun mempertimbangkan model/metode ajar yang akan digunakan dan pembelajaran yang berpusat pada peserta didik.

Perencanaan diawali dengan kegiatan menganalisis dan mengidentifikasi kebutuhan dan permasalahan yang mungkin akan dihadapi selama pembelajaran. Analisis dan identifikasi meliputi tujuan akhir pembelajaran yang ingin dicapai, cara mengajarkannya, bagaimana mensiasati kekurangan fasilitas dan sarana belajar, dan sebagainya. Sehingga dapat diketahui berbagai kondisi nyata yang akan digunakan untuk kepentingan open lesson.

Setelah melakukan identifikasi, selanjutnya secara bersama-sama mencari solusi untuk memecahkan permasalahan-permasalahan yang ditemukan. Kesimpulan dari hasil analisis dan identifikasi tersebut menjadi pertimbangan dalam menyusun lesson design sehingga menjadi sebuah perencanaan yang matang, yang didalamnya sanggup mengantisipasi segala kemungkinan yang akan terjadi selama pelaksanaan pembelajaran berlangsung.

\section{b) Tahapan Pelaksanaan (Do)}

Pada tahap pelaksanaan terdapat dua kegiatan utama: (1) kegiatan pelaksanaan pembelajaran yang telah dituangkan dalam lesson design, dan (2) kegiatan pengamatan atau observasi yang dilakukan anggota atau komunitas lesson study (pimpinan institusi, dosen, atau undangan lainnya yang bertindak sebagai pengamat/observer).

Beberapa hal yang harus diperhatikan dalam tahapan pelaksanaan, diantaranya:

1) Dosen model melaksanakan pembelajaran sesuai dengan lesson design yang telah disusun pada tahap awal.

2) Mahasiswa diupayakan melakukan proses belajar secara wajar dan natural, tidak dalam keadaan tertekan akibat adanya kegiatan lesson study.

3) Selama kegiatan open lesson, pengamat tidak diperkenankan berinteraksi dengan mahasiswa sehingga mengganggu jalannya kegiatan open lesson dan 
mengganggu konsentrasi dosen model maupun mahasiswa.

4) Yang diobservasi secara teliti oleh observer adalah bagaimana interaksi mahasiswa dengan mahasiswa, mahasiswa dengan bahan ajar, mahasiswa dengan guru, mahasiswa dengan lingkungan lainnya.

5) Observer dapat belajar dari pembelajaran yang berlangsung pada saat open lesson dan bukan untuk mengevalusi bagaimana dosen model mengajar.

6) Observer dapat melakukan perekaman melalui video camera atau photo digital untuk keperluan dokumentasi dan bahan analisis yang disampaikan pada saat melakukan refleksi.

7) Observer mencatat perilaku belajar mahasiswa selama pembelajaran berlangsung, misalnya tentang komentar atau diskusi mahasiswa dengan mencantumkan nama yang bersangkutan, terjadinya proses konstruksi pemahaman peserta didik melalui aktivitas belajar mahasiswa.

\section{c) Tahapan Refleksi (Check)}

Tahapan ini merupakan tahapan yang paling penting dalam kegiatan lesson study. Perbaikan proses pembelajaran yang akan dilakukan akan sangat bergantung dari bagaimana ketajaman analisis observer selama pembelajaran berlangsung. Kegiatan refleksi dilakukan dengan cara diskusi yang diikuti seluruh komunitas lesson study yang dipandu oleh seorang moderator yang telah ditunjuk sebelumnya.

Diskusi dimulai dengan penyampaian praktik pembelajaran yang telah dilaksanakan oleh dosen model untuk mengetahui kesan umum selama pembelajaran berlangsung. Pada tahap ini disampaikan pula hambatan dalam melaksanakan lesson design yang telah disusun sehingga peseta diskusi dapat mengidentifikasi masalah-masalah yang timbul selama pembelajaran belangsung untuk didiskusikan bersam-sama.

Setelelah dosen model menyampaikan kesan umum selama pembelajaran berlangsung, semua peserta diskusi memberikan tanggapan atau saran secara bijak terhadap proses pembelajaran yang telah dilaksanakan (bukan terhadap guru yang bersangkutan). Dalam menyampaikan tanggapan dan saran, peserta diskusi menyampaikannya berdasarkan fakta yang terjadi berdasarkan pengamatan dan didukung oleh bukti-bukti, tidak berdasarkan opini. Berbagai pendapat yang berkembang selama diskusi dapat dijadikan bahan refleksi bagi masing-masing peserta untuk perbaikan atau peningkatan proses pembelajaran pada mata kuliah yang diampu.

\section{d) Tahapan Tindak Lanjut (Act)}

Setelah melakukan refleksi terhadap proses pembelajaran, maka akan diperoleh poin-poin penting untuk perbaikan dan peningkatan proses pembelajaran, baik pada tataran dosen sebagai pengajar, maupun pemangku kepantingan sebagai penentu kebijakan. Pada tataran dosen sebagai pengajar, berbagai temuan yang didapat pada saat diskusi tentunya menjadi modal yang baik untuk mengembangkan proses pembelajaran ke arah lebih baik. Sedangkan pada tataran pemangku kepentingan sebagai penentu kebijakan, akan diperoleh sejumlah masukan yang berharga bagi kepentingan pengembangan manajemen pendidikan di lembaga yang dipimpinnya. Keterlibatan pimpinan dalam pelaksanaan lesson study juga merupakan salah satu bentuk bentuk kepedulian terhadap penjaminan mutu lembaga pada proses pembembelajaran.

\section{Dampak Penerapan Lesson Study Melalui Metode Problem Based Learning (PBL) Dalam Meningkapkan Keaktifan peserta didik}

Tabel 1

Rekapitulasi Keaktifan Belajar Peserta Didik Pada Pembelajaran

\begin{tabular}{|c|c|c|c|c|}
\hline \multirow{2}{*}{ No } & \multirow{2}{*}{ Aspek yang Diamati } & \multicolumn{3}{|c|}{ Kriteria } \\
\hline & & B & C & K \\
\hline 1. & $\begin{array}{l}\text { Kegiatan visual (visual activities), yaitu membaca, memperhatikan gambar, } \\
\text { mengamati demonstrasi atau mengamati pekerjaan orang lain }\end{array}$ & & V & \\
\hline 2. & $\begin{array}{l}\text { Kegiatan lisan (oral activities), yaitu kemampuan menyatakan, merumuskan, } \\
\text { diskusi, bertanya atau interupsi }\end{array}$ & & $\mathrm{V}$ & \\
\hline 3. & $\begin{array}{l}\text { Kegiatan mendengarkan (listening activities), yaitu mendengarkan penyajian } \\
\text { bahan, diskusi atau mendengarkan percakapan }\end{array}$ & $\mathrm{V}$ & & \\
\hline 4. & $\begin{array}{l}\text { Kegiatan menulis (writing activities), yaitu menulis cerita, mengerjakan soal, } \\
\text { menyusun laporan atau mengisi angket }\end{array}$ & & & V \\
\hline 5. & $\begin{array}{l}\text { Kegiatan menggambar (drawing activities), yaitu melukis, membuat grafik, pola, } \\
\text { atau gambar }\end{array}$ & & & V \\
\hline 6. & Kegiatan emosional (emotional activities), yaitu menaruh minat, memiliki & $\mathrm{V}$ & & \\
\hline
\end{tabular}


kesenangan atau berani

7. Kegiatan motorik (motor activities), yaitu melakukan percobaan, memilih alatalat atau membuat model

8. Kegiatan mental, yaitu mengingat, memecahkan masalah, menganalisis, melihat hubungan-hubungan atau membuat keputusan

9. Bertingkah laku sebagai pemimpin, dapat bergaul dengan orang lain Sumber : Hasil Pengolahan Data

Tabel 2 menginformasikan rerata pendapat mahasiswa terhadap indikator-indikator dari dimensi tentang memberikan orientasi permasalahan kepada peserta didik berkisar antara 3,87 - 4,26. Dapat peneliti persepsikan bahwa seluruh indikator dalam dimensi tentang memberikan orientasi permasalahan kepada peserta didik telah berlangsung baik. Dari ke lima indikator tersebut terlihat indikator sebelum belajar dimulai, saya mendapat penjelasan dari guru mengenai tujuan belajar memiliki rerata paling tinggi yakni 4,26. Rerata ini menyiratkan bahwa peserta didik harus mendapatkan kejelasan dari tujuan ia belajar, karena dari tujuan yang disampaikan oleh guru peserta didik secara tidak langsung mengukur dirinya terhadap pengetahuan yang ia miliki. Maka dari aktivitas peserta didik seperti adanya peserta didik yang bertanya atau tidak bertanya merupakan informasi untuk guru terhadap peserta didik yang belum optimal dalam belajarnya.

Tabel 3

Pendapat Mahasiswa Tentang Mengorganisasikan Peserta Didik Untuk Meneliti

\begin{tabular}{|c|c|c|c|}
\hline No & Aspek & Rata-rata & Kategori \\
\hline 10 & $\begin{array}{l}\text { Guru membagi kelompok kecil dalam kelompok tersebut saya } \\
\text { berinteraksi dengan anggota dan kelompok lain }\end{array}$ & 4,29 & Sangat Baik \\
\hline 11 & $\begin{array}{l}\text { Saya mendapat lembar kegiatan yang didalamnya terdapat masalah } \\
\text { yang harus dipecahkan oleh kelompok }\end{array}$ & 4,50 & Sangat Baik \\
\hline 12 & $\begin{array}{l}\text { Saya dibimbing oleh guru untuk menentukan subtopik berdasarkan } \\
\text { permasalahan yang terdapat di lembar kegiatan }\end{array}$ & 4,08 & Baik \\
\hline 13 & $\begin{array}{l}\text { Saya mendapat tugas dalam penyelidikan untuk memecahkan } \\
\text { masalah }\end{array}$ & 4,37 & Sangat Baik \\
\hline 14 & $\begin{array}{l}\text { Saya bersama kelompok membuat jadwal penyelidikan dengan } \\
\text { membuat tabel penyelidikan pemecahan masalah }\end{array}$ & 4,18 & Baik \\
\hline 15 & $\begin{array}{l}\text { Saya didampingi oleh guru utuk membuat rumusan masalah } \\
\text { berdasarkan lembar kegiatan }\end{array}$ & 4,34 & Sangat Baik \\
\hline \multirow[t]{2}{*}{16} & $\begin{array}{l}\text { Saya mendapat dorongan dari guru untuk melakukakan pekerjaan } \\
\text { dengan baik }\end{array}$ & 3,32 & Cukup Baik \\
\hline & Jumah rata-rata & 4,29 & Sangat Baik \\
\hline
\end{tabular}

Sumber : Hasil Pengolahan Data

Tabel 3 menginformasikan rerata pendapat mahasiswa terhadap indikator-indikator dari dimensi tentang mengorganisasikan peserta didik untuk meneliti dipersepsikan bahwa seluruh indikator dalam dimensi tentang mengorganisasikan peserta didik untuk meneliti telah berlangsung sangat baik. Dari ke tujuh pernyataan tersebut terlihat pernyataan saya mendapat lembar kegiatan yang didalamnya terdapat masalah yang harus dipecahkan oleh kelompok memiliki rerata paling tinggi yakni 4,50. Rerata ini menyiratkan bahwa pertanyaan merupakan 'alat' mengajar yang penting untuk mendorong peserta didik berpikir. Karena itu, guru perlu menguasainya. pertanyaan yang diajukan guru sering lebih menuntut peserta didik untuk mengulang gagasan yang telah dikemukakan guru daripada memproduksi gagasan peserta didik sendiri. Pertanyaan yang baik dapat dijadikan komponen utama lembar kerja (LK). LK sering berfungsi sebagai pelengkap penjelasan guru tentang suatu konsep daripada sebagai pemicu penemuan konsep itu sendiri.

Tabel 4

Pendapat Mahasiswa Tentang Membantu Investigasi Mandiri dan Kelompok

\begin{tabular}{r|l|c|c}
\hline No & \multicolumn{1}{|c}{ Aspek } & Rata-rata & Kategori \\
\hline 17 & $\begin{array}{l}\text { Saya mendapat tugas individu dalam mencari informasi untuk } \\
\text { memecahkan masalah }\end{array}$ & 3,89 & Baik \\
\hline 18 & Saya mendapat tugas yang berbeda dari teman sekelompok untuk & 4,26 & Sangat Baik \\
\hline
\end{tabular}


Almujab, S., Yogaswara, S.M., Novendra, A.M., dan Maryani, L. / Jurnal Refleksi Edukatika 8 (2) (2018)

mencari informasi dalam memecahkan masalah

\section{Sumber: Hasil Pengolahan Data}

Jumah rata-rata

4,07

Baik

Tabel 4 menginformasikan rerata pendapat mahasiswa terhadap indikator-indikator dari dimensi tentang membantu investigasi mandiri dan kelompok telah berlangsung baik. Dari ke dua pernyataan tersebut terlihat pernyataan saya mendapat tugas yang berbeda dari teman sekelompok untuk mencari informasi dalam memecahkan masalah memiliki rerata paling tinggi yakni 4,26. Rerata ini menyiratkan bahwa pemberian tugas yang berbeda, produk yang berbeda, isi yang berbeda sesuai dengan kemampuan peserta didik merupakan strategi pembelajaran untuk individu berbeda. Semua peserta didik memiliki hak untuk belajar dan memperoleh pendidikan yang berkualitas, termasuk peserta didik yang berbakat dan mengalami gangguan kecerdasan. Setiap guru diharapkan memiliki pemahaman yang baik tentang keberagaman kondisi peserta didik, agar dapat memberikan pelayanan pendidikan yang sesuai dengan kebutuhan dan keunikan peserta didik.

Tabel 5

Pendapat Mahasiswa Tentang Mengembangkan dan Mempresentasikan Artefak

\begin{tabular}{|c|c|c|c|}
\hline No & Aspek & Rata-rata & Kategori \\
\hline 19 & $\begin{array}{l}\text { Saya mendapat informasi dan saya mampu membuat ide untuk } \\
\text { memecahkan masalah }\end{array}$ & 3,39 & Cukup Baik \\
\hline 20 & $\begin{array}{l}\text { Saya bersama kelompok saling melaporkan informasi secara lisan, } \\
\text { menerima umpan balik dari teman yang berbeda informasi }\end{array}$ & 4,16 & Baik \\
\hline 21 & $\begin{array}{l}\text { Saya bersama kelompok dibimbing oleh guru untuk menyusun } \\
\text { tugas kelompok. }\end{array}$ & 3,87 & Baik \\
\hline 22 & $\begin{array}{l}\text { Saya menulis laporan secara individu berdasarka informasi yang } \\
\text { saya peroleh. }\end{array}$ & 4,11 & Baik \\
\hline 23 & $\begin{array}{l}\text { Saya dibimbing oleh guru untuk saling membacakan laporan dan } \\
\text { memberi masukan di dalam kelompok kerja }\end{array}$ & 4,08 & Baik \\
\hline 24 & Saya memperbaiki laporan berdasarkan masukan dari teman & 3,82 & Baik \\
\hline \multirow[t]{2}{*}{25} & $\begin{array}{l}\text { Saya bersama kelompok membuat model (perwujudan secara fisik } \\
\text { dari situasi masalah dan pemecahannya) }\end{array}$ & 3,16 & Cukup Baik \\
\hline & Jumah rata-rata & $\mathbf{3 , 8 0}$ & Baik \\
\hline
\end{tabular}

Sumber: Hasil Pengolahan Data

Tabel 5 menginformasikan rerata pendapat mahasiswa terhadap indikator-indikator dari dimensi tentang mengembangkan dan mepresentasikan telah berlangsung baik. Dari ke tujuh pernyataan tersebut terlihat pernyataan saya bersama kelompok saling melaporkan informasi secara lisan, menerima umpan balik dari teman yang berbeda informasi memiliki rerata paling tinggi yakni 4,16. Rerata ini menyiratkan bahwa pelaksanaan pembelajaran berjalan dengan baik, peserta didik melakukan diskusi dalam kelompok profesi: masing-masing anggota kelompok melaporkan informasi yang diperoleh. Anggota kelompok lainnya bisa bertanya dan memberi umpan balik.

Tabel 6

Pendapat Mahasiswa Tentang Menganalisis dan Mengevaluasi Proses Mengatasi Masalah

\begin{tabular}{|c|l|c|c|}
\hline No & \multicolumn{1}{|c|}{ Aspek } & Rata-rata & Kategori \\
\hline 22 & $\begin{array}{l}\text { Saya bersama kelompok dibimbing oleh guru untuk melakukan } \\
\text { presentasi hasil karya dan mengkomunikasikan dengan kelompok } \\
\text { lain }\end{array}$ & 4,08 & Baik \\
\hline $\begin{array}{l}\text { Saya mendapat kesimpulan, penguatan dan pemberian informasi } \\
\text { lebih lanjut dari guru dan hasil karya mendapat penilaian dari teman } \\
\text { dan guru }\end{array}$ & 3,39 & Cukup Baik \\
\hline & Jumah rata-rata & $\mathbf{3 , 7 4}$ & Baik \\
\hline
\end{tabular}

Sumber: Hasil Pengolahan Data

Tabel 6 menginformasikan rerata pendapat mahasiswa terhadap indikatorindikator dari dimensi tentang menganalisis dan mengevaluasi proses mengatasi masalah telah berlangsung baik. Dari ke dua pernyataan tersebut terlihat pernyataan saya bersama kelompok dibimbing oleh guru untuk melakukan presentasi hasil karya dan 
mengkomunikasikan dengan kelompok lain memiliki rerata paling tinggi yakni 4,08. Rerata ini menyiratkan bahwa dalam melakukan aktivitas presentasi telah terjadi interaksi dimana kelompok penyaji memberikan oreintasi masalah sampai dengan mengevaluasi masalah kelompok yang disajikan memberikan sanggahan atau unpan balik terhadap permasalahan yang dipegang oleh kelompok penyaji.

Dengan mengacu pada perolehan pelaksanaan tindakan siklus I diperoleh beberapa refleksi yang dihasilkan dari diskusi dengan oserver untuk perbaikan pada siklussiklus selanjutnya. Adapun hasil reflesi sebagai berikut:

a) Guru harus lebih meningkatkan lagi pelaksanaan pembelajarannya, terutama dalam pengelolaan kelas dan apersepsi;

b) Guru harus menyampaikan tujuan pembelajaran secara berurutan agar peserta didik sebelum pembelajaran dimulai;

c) Sebelum memulai pembelajaran sebaiknya peserta didik dibentuk kelompok dahulu sehingga lebih tertib dan disiplin;

d) Dalam pembahasan tugas hasil belajar seharusnya dilakukan secara giliran sehingga peserta didik merasa terkondisikan dan tidak gaduh lagi; dan

e) Dalam menyimpulkan materi sebaiknya melibatkan semua peserta didik bukan hanya melibatkan yang pintar saja.

\section{SIMPULAN}

Berdasarkan hasil penelitian dan analisis terhadap hasil penelitian tersebut dapat disimpulkan hal-hal sebagai berikut:

1) Lesson study merupakan kegiatan pendampingan dan pembinaan terhadap pengajar mulai dari melakukan persiapan (plan), pelaksanaan (do), refleksi (check or see) dan tindak lanjut (act).

(a) Kegiatan plan merupakan kegiatan menganalisis dan mengidentifikasi kebutuhan dan permasalahan yang mungkin akan dihadapi selama pembelajaran.

(b) Pada tahap pelaksanaan terdapat dua kegiatan utama: (1) kegiatan pelaksanaan pembelajaran yang telah dituangkan dalam lesson design, dan (2) kegiatan pengamatan atau observasi yang dilakukan anggota atau komunitas lesson study (pimpinan institusi, dosen, atau undangan lainnya yang bertindak
pengamat/observer).

sebagai

(c) Kegiatan refleksi dilakukan dengan cara diskusi yang diikuti seluruh komunitas lesson study yang dipandu oleh seorang moderator yang telah ditunjuk sebelumnya.

(d) Tahap tindak lanjut merupakan tahapan pelaksanaan hasil refleksi yang telah dilakukan.

2) Hasil dari pelaksanaan tindakan siklus I dapat diidentifikasi bahwa secara umum pelaksanaan tindakan belum mencapai hasil yang memuaskan. Pada siklus I secara umum keaktifan mahasiswa dalam pembelajaran termasuk pada kategori sedang. Sementara berdasarkan hasil kuisioner tentang pelaksanaan pembelajaran diperoleh informasi bahwa sebagaian besar peserta didik merasa senang dengan pembelajaran ekonomi dengan menggunakan metode belajar PBL. Hal ini disebabkan karena pembelajaran dengan menggunakan PBL mampu membangkitkan aktifitas belajar mahasiswa dalam pembelajaran.

\section{DAFTAR PUSTAKA}

Baba, T. (2007). How is Lesson Study Implemented?". Japanese Education and Lesson Study: An Overview, (1), 2-71.

Barrett, A., Tikly, L., Guoxing, Y., \& Sajid, A. (2007). Initiatives to improve the quality of teaching and learning. A review of recent literature. Background paper prepared for the Global Monitoring Report 2008. Unesco. Retrieved from http://unesdoc.unesco.org/images/0015/00 1555/155504e.pdf\%5Cnhttp://dare.uva.nl/r ecord/293352

Bryman, A., \& Bell, E. (2011). Business Research Methods. New York: Oxford University Press. Retrieved from https://www.worldcat.org/title/businessresearchmethods/oclc/932123876\&referer=brief_re sults

Cajkler, W., Wood, P., Norton, J., Pedder, D., \& $\mathrm{Xu}, \mathrm{H}$. (2015). Teacher perspectives about lesson study in secondary school departments: a collaborative vehicle for professional learning and practice development. Research Papers in Education, 30(2), 192-213. 
Darling-Hammond, L. (1997). Doing Matters Most: Investing in Quality Teaching. New York.

Denscombe, M. (2017). The Good Research Guide small-scale social research projects (6th ed.). London: Open University Press. https://doi.org/10.1371/journal.pone.00175 40

Dinus. (2016). Menuju guru yang profesional melalui lesson study. Retrieved November 9, 2017, from https://educatinalwithptkdotnet.files.wordp ress.com/2013/01/19-menuju-guru-yangprofesional-melalui-lesson-study.pdf.

Dudley, P. (2014). Lesson Study: A handbook. Www.Lessonstudy.Co.Uk, 1-17. Retrieved from http://lessonstudy.co.uk/wpcontent/uploads/2012/03/Lesson_Study_H andbook_-_011011-1.pdf

Hamalik, O. (2007). Proses Belajar Mengajar. Jakarta: Bumi Aksara.

Kemmis, S., \& McTaggart, R. (2007). Participatory action research: Communicative action and the public sphere. Strategies of qualitative inquiry. Geelong, Australia: Deakin University Press. https://doi.org/10.1080/096507906009755 93

Krisnawan. (2010). Penerapan Metode Lesson Study Dalam Pembentukan Pendidikan Yang Berkarakter. Surakarta.

Laila Nursafitri. (2015). Peningkatan Kualitas Pembelajaran Melalui Lesson Study. Portal Garuda. Lampung. Retrieved from http://download.portalgaruda.org/article.ph p?article $=374769 \&$ val $=7241 \&$ title $=$ IMPR OVING THE QUALITY OF LEARNING THROUGH LESSON STUDY.

Lewis, C. (2002). Lesson Study: A Handbook for Teacher-led Improvement of Instruction. Research for Better Schools, 1-5. Retrieved from http://www.lessonresearch.net/briefguide.p df
Putri, I., Atmazaki, \& Syahrul. (2013). Pelaksnaan Lesson Study Dalam Pembelajaran Bahasa Indonesia peserta didik Kelas VII.5 MTsN Lubukbuaya Padang. Jurnal Bahasa, Sastra Dan Pembelajaran, 1(1), 108-117.

Sardiman, A. M. (2001). Interaksi dan Motivasi Belajar Mengaja. Jakarta: Raja Grafindo Persada.

Stringer, E. T. (2014). Action Research (4th ed.). California: Thousand Oaks. https://doi.org/10.1177/147675030934997 6

Suratno, T. (2012). Lesson study in Indonesia: an Indonesia University of Education experience. International Journal for Lesson and Learning Studies, 1(3), 196215. https://doi.org/10.1108/204682512112564 10

Takahashi, A., \& Thomas, M. (2014). Implementing a new national curriculum: Case study of a Japanese school's 2 -year Lesson Study project. Implementing curriculum.

UNESCO. 2015. Good Quality Education, Provided by Trained and Supported Teachers, Is The Right of All Children, Youth and Adults, Not The Privilege of The Few. Retrieved from https://en.unesco.org/world-educationforum-2015/5-key-themes/qualityeducation

UNICEF. 2000. Defining Quality in Education. In The International Working Group on Education Florence (pp. 1-36).

Wiharto, M. 2017. Kegiatan Lesson Study Dalam Pembelajaran. In FGD-Pengayaan Pengembangan Kurikulum Pendidikan Tinggi. Kementrian Riset Teknologi dan Pendidikan Tinggi (pp. 22-30). 